\title{
Humanitarian Cooperation between Russia and China within the Shanghai Cooperation Organization*
}

\author{
Anatoly Tsvyk \\ Department of Theory and History of International \\ Relations \\ Peoples ' Friendship University of Russia \\ 6 Miklukho-Maklaya Str. \\ Moscow, Russia \\ E-mail: tsvyk_av@rudn.university
}

\author{
Galina Tsvyk \\ Department of Theory and History of International \\ Relations \\ Peoples ' Friendship University of Russia \\ 6 Miklukho-Maklaya Str. \\ Moscow, Russia \\ E-mail: tsvyk_gi@rudn.university
}

\begin{abstract}
The article is devoted to the development of Russian-Chinese humanitarian cooperation within the framework of the Shanghai Cooperation Organization. The author analyzes main aspects of humanitarian cooperation between the SCO member states, due to the fact that cooperation in this field is very important within the Shanghai Cooperation Organization's agenda. At the same time, the special significance of Russian-Chinese relations in this sphere is highlighted in connection with the fact that Russia and China were the first among Shanghai Cooperation Organization's member states to declare humanitarian cooperation. Since that time both countries were actively developing bilateral cooperation in various spheres. The article examines various spheres of humanitarian relations within the Shanghai Cooperation Organization, namely education, culture, academic mobility, sports and tourism. Recently, the humanitarian component has become increasingly important in Russian-Chinese cooperation, which in the last two decades has begun to include not only traditional spheres of interaction such as culture and education, but also health, sports, mass media and tourism. In addition, after the establishment of strategic partnership between the Russian Federation and the People's Republic of China, humanitarian cooperation, having received great state support, began to develop very fast. With the advent of a new international regional organization, which member-states are Russia, China, Kazakhstan, Kyrgyzstan, Turkmenistan, Uzbekistan, and since 2017, India and Pakistan, a new format of bilateral cooperation between Moscow and Beijing in the framework of the Shanghai Cooperation Organization has emerged.
\end{abstract}

Keywords-Russia; China; Shanghai Cooperation Organization; humanitarian cooperation; education; cultural ties

\section{INTRODUCTION}

Active participation in international humanitarian cooperation is one of the focal points of each country's foreign policy in terms of ensuring its national interests in the international arena. In this regard, the concept of international humanitarian cooperation exhibits a

*The publication was prepared with the support of the "RUDN University Program 5-100". comprehensive content including intergovernmental cooperation in matters of culture, science, information, sports, tourism, etc. [1]. National authorities and international organizations recognize the importance of humanitarian cooperation, investing significant financial resources in its development.

The humanitarian component in terms of the Shanghai Cooperation Organization is given high importance, because one of the goals of the Organization's development is to create a common humanitarian space.

According to the Shanghai Cooperation Organization's Charter, cooperation in the humanitarian sphere is one of the Organization's priorities. Article 3 of the SCO Charter dated June 7, 2002, defines the main areas of cooperation within the Organization, including humanitarian cooperation, namely "development of interaction in such spheres as science and technology, education, health care, culture, sports and tourism" [2]. The heads of the Shanghai Cooperation Organization member states have repeatedly stressed that the Organization should pay more attention to the humanitarian agenda, which is becoming one of the dynamically developing spheres of interaction both in terms of the Shanghai Cooperation Organization and on a bilateral basis among the Organization's member states.

The most successful and productive areas of humanitarian cooperation within the SCO are education and culture, while cooperation in terms of health care has also recently shown a growing trend.

\section{HUMANITARIAN COOPERATION WITHIN THE SHANGHAI COOPERATION ORGANIZATION}

Over the years of performance of the Shanghai Cooperation Organization, the member states have established practical cooperation in the spheres of culture, education, science and technology, sports, tourism, environmental protection, health care, youth policy and the media. Ministers of Culture of the SCO member states adopted a program of multilateral cultural cooperation within the Organization at one of the first meetings of the relevant 
heads of departments. Since 2005, the festival of culture and arts has been held in parallel with the SCO summit.

At the same time, the member states of the Organization pay special attention to the cooperation in the spheres of art, science and technology. It has become a tradition for member states and observers of the Organization to hold various art events during the Shanghai Cooperation Organization summits. Moreover, SCO member state ministries of education, science and culture hold regular meetings as well. It is worth noting the annual arts festival held in terms of the SCO summits.

Cooperation in the humanitarian sphere has laid a solid foundation to strengthen friendship between the Shanghai Cooperation Organization's members, with a growing development trend [3]. Thanks to the specific humanitarian resources of each country, the Organization's member states possess a great potential for interaction. First of all, we should note centuries-old close cultural ties among the peoples of Central Asia, which improve mutual understanding among them and contribute to the enrichment of each other's national cultures. At the same time, the roots of China's relations with the countries of Central Asia also go back to the distant past. It is known that the Great Silk Road of Antiquity was the main route of intercultural communication between China and the peoples of Central Asia, and the current One Belt One Road Initiative being implemented by China is meant to promote improvement of cooperation between the peoples of China and Central Asia. At the same time, one should note that through centuries the countries of the Central Asian region have been greatly influenced by the Russian culture. Russian is the universal language of communication in the region. Therefore, the Shanghai Cooperation Organization provides unique conditions to facilitate the humanitarian exchange and cooperation among its member states.

\section{CULTURAL COOPERATION BETWEEN RUSSIA AND CHINA WITHIN THE SCO}

Considering the cultural sphere of interaction within the Shanghai Cooperation Organization, it is worth noting that the Organization initially positioned itself as a structure seeking to develop all aspects of international humanitarian cooperation. Its founding document, the SCO Charter, says that cooperation in the humanitarian sphere is one of the Organization's priorities.

In April 2007, this scope of cooperation was consolidated in the Treaty on Long-Term Good Neighborliness, Friendship and Cooperation between the Member States, signed at the Shanghai Cooperation Organization summit in Bishkek [4]. This document stepped up the cultural exchange and increased the number of cultural events held.

In April 2009, during the Meeting of the Ministers of Culture of the SCO member states in Kazan, the Declaration of the Meeting of the Ministers of Culture of the Member States of the Shanghai Cooperation Organization was adopted, giving great importance to cooperation in the sphere of youth policy and the youth's role in preserving the national cultural heritage and development of multilateral cultural cooperation. Consequently, on May 4, 2009 in Yekaterinburg, the member states of the Organization signed the Declaration on the Establishment of the SCO Youth Council.

Every year the number of jointly held cultural events within the Shanghai Cooperation Organization is increasing, their agenda becoming more and more extensive. Such events positively promote the development and improvement of cultural ties among the peoples of the SCO member states, complemented with the Organization's growing authority in the international arena. The Shanghai Cooperation Organization is becoming a platform for effective political and economic cooperation, while formation of a common cultural space is undoubtedly contributing to a closer convergence of the peoples and the countries participating in the Organization.

Formation of a common cultural and information space is one of the most important productive and efficient mechanisms helping to expand the boundaries of human understanding of the world's diversity, of the deep internal processes and various transformations taking place in the global society. It is the common cultural and information space that is able to ensure a significant breakthrough in the peoples' progress towards peaceful coexistence and joining creative efforts.

Therefore, the Shanghai Cooperation Organization has a great medium- to long-term potential for implementing and improving multilateral humanitarian cooperation in the cultural sphere, both within the SCO and with the observer countries and partners.

\section{EDUCATIONAL COOPERATION BETWEEN MOSCOW AND BEIJING WITHIN THE SHANGHAI COOPERATION ORGANIZATION}

The main tasks in the educational sphere of Russia and China are information exchange, stimulation of direct cooperation among institutions of higher education of the member states, formation of a list of institutions to cooperate, mutual language support to educational programs and much more [5]. Particular attention is paid to Russian and Chinese applicants to masters' and postgraduate degree programs [6].

On October 26, 2005, the Council of Heads of Governments of the SCO member states adopted a resolution to intensify cooperation in the educational sphere including meetings of ministers of education of the SCO member states and creation of a permanent educational expert task group.

On June 15, 2006 in Shanghai, the governments of the SCO member states signed the Agreement on Cooperation in Education, laying the foundation for the development of multilateral educational cooperation among the SCO member states. According to this agreement, the member states of the Organization contemplate to support the development of integration processes in the field of education, to promote mutual exchange of students, scientists and teachers, to share information on educational matters, to encourage the study of languages, history, and culture of the SCO member states. 
On October 18, 2006 in Beijing, the ministers of education of the SCO member states held their first meeting, where the parties agreed to establish a mechanism of multilateral cooperation in education and outlined the main lines and tasks of cooperation in education within the SCO. The main lines of multilateral cooperation of the SCO member states in the sphere of education are as follows:

- Exchange of experience and information on reforms carried out in the sphere of education in the SCO member states;

- Development of integration processes in the sphere of education and, consequently, creation of an information and regulatory framework on the education-related policy issues of the Shanghai Cooperation Organization's member states;

- Mutual exchange of students, scientists and teachers of educational institutions and organizations of the SCO member states;

- Cooperation in improving the quality of education;

- Creation of mechanisms to ensure transparency and comparability of qualifications and educational certificates, recognition and establishment of equivalence of official educational certificates issued by educational institutions and organizations of SCO member states.

It is also necessary to point out that before 2007, the Shanghai Cooperation Organization did not have unified approaches to the issues of export and import of educational services. Moreover, there was no unified information center for educational services of the SCO member states. To solve this issue, a special SCO website was launched. Since 2007 the Organization has also been issuing the Newsletter on cooperation in education.

At the same time, it should be noted that since 2008 the Organization regularly holds the Week of Education of the SCO member States, the forum for the leading university rectors, and since 2009 the forum has also included rectors of state service academies of SCO member states.

Cooperation in the spheres of education and science between Russia and China within the Shanghai Cooperation Organization promotes improvement of traditional relations, contributing to the development of relations in other areas. One of the future prospects for such cooperation can include creation of a common educational service market, strengthening the integration trends in the region. However, in this case it should imply creation of a new, common educational space based on mutual trust and cooperation, rather than the dominant role of any of the member states of the Shanghai Cooperation Organization.

At the same time, the Shanghai Cooperation Organization faces the task of developing common standards of education and free exchange of knowledge and specialists. According to Russian experts, "solution of these problems will expand the opportunities of Russian universities to provide educational services to the citizens of SCO member states, also helping to increase the competitive performance of Russian education and the export of Russian educational services to the Asian mainland" [7]. Implementation of the idea to found the University of the Shanghai Cooperation Organization, proposed by Vladimir Putin in 2007, will also serve these goals.

\section{CONCLUSION}

To date, the Shanghai Cooperation Organization has become a multidisciplinary organization enjoying international influence and authority. One should note that the most important factor here is the search for new forms of interaction, including humanitarian cooperation, comprising education, cultural ties, medicine, tourism, etc. One of the main problems of humanitarian cooperation within the SCO is that the Organization brings together countries having different cultural traditions, languages and educational systems.

In our opinion, the development of relations between Russia and China is an important factor in the development of the Shanghai Cooperation Organization. Bilateral cooperation between the two countries within the Organization largely determines the trends in the entire SCO region. The Russian-Chinese humanitarian cooperation plays an important role here, including the Russian-Chinese Commission for Humanitarian Cooperation (with subcommittees on education, culture, tourism and medicine), establishment of the University of the Shanghai Cooperation Organization, launching cultural centers, holding exhibitions, years of national culture [8]. For a long time, humanitarian cooperation in the Shanghai Cooperation Organization was bilateral, for example, in terms of the Russian-Chinese Commission for Humanitarian Cooperation, the SinoKazakh Subcommittee on Cultural and Humanitarian Cooperation, etc. With the development of cooperation in the SCO region, the bilateral platform expands to embrace multilateral cooperation, however following the same principles of interaction [9]. Permanent expert commissions are being established in the spheres of education, culture, health care, and it is planned to create similar multilateral commissions on sports, tourism, media, etc.

At the same time, in our opinion, it is necessary to improve the legal and regulatory framework of the RussianChinese bilateral and multilateral humanitarian cooperation within the Shanghai Cooperation Organization, vesting it with broader functions and powers, and expanding the areas of humanitarian cooperation [10]. Simultaneously, it is important to consider the option of increasing the presence of various Russian governmental, commercial and public organizations in the territories of the SCO member states to popularize the Russian language and culture. Special attention should be paid to the training of highly qualified sinologists, to a wider promotion of the Russian school of Sinology, and to the increase of quotas for Russian students, specialists and postgraduate students to receive free education in universities of China.

Bigger additional efforts will be required not to lose the pace set by the Shanghai Cooperation Organization since the 
Ufa summit. The jubilee meeting of the heads of the SCO member states in June 2016 in Tashkent confirmed the continuity of the Organization's positive momentum, and as early as in June 2017 Astana hosted a historic meeting of the Council of Heads of Member States of the Shanghai Cooperation Organization, where the status of an SCO member state was granted to the Republic of India and the Islamic Republic of Pakistan. It should be noted that the expansion of the Shanghai Cooperation Organization and further improvement of cooperation with observer states and partners is of great importance for the development and enhancement of the Organization's potential. The success of the SCO evolution in the humanitarian sphere will be largely influenced by the common aspiration of all the member states, and, first of all, by the prospects of the relevant bilateral cooperation between Russia and China. They will further stimulate the development and introduction of new initiatives upon the multilateral cooperation platform within the Shanghai Cooperation Organization.

\section{REFERENCES}

[1] V.M. Filippov, Internationalization of Higher Education: Major Trends, Challenges and Prospects. // Vestnik RUDN. International Relations, 15 (3), pp. 203-211.

[2] Charter of the Shanghai Cooperation Organization. Available at: en.sco-russia.ru/load/1013181846 (accessed: 10.04.2018).

[3] R.M. Valeev, A.R. Alikberova, Humanitarian communication in the system of Russian-Chinese relations: results of research work // The Turkish Online Journal of Design, Art and Communication TOJDAC. Special Edition. 2016, pp. 2358-2363. DOI: 10.7456/1060NVSE/029.

[4] Cultural-humanitarian cooperation within the Shanghai Cooperation Organization. Web-site of the SCO. Available at: http://infosco.biz/ru/?pageId=231 (accessed: 13.04.2018).

[5] A. Tsvyk, G. Tsvyk, The Russian-Chinese Cooperation in the Humanitarian Sphere. Proceedings of the 2017 4rd International Conference on Education, Language, Art and Inter-Cultural Communication. (ICELAIC 2017). Advances in Social Science, Education and Humanities Research, Volume 142. Moscow, Russia, 17-18 October, 2017. Paris: Atlantis Press, 2017, pp. 694-696.

[6] E. Medianik, Joint Universities as a Tool for Promoting the National Interests of Russia and China. 2017. International Organisations Research Journal, Vol. 12, No .1, pp. 7-23 (in Russian and English). DOI: 10.17323/1996- 7845-2017-01-7.

[7] L.I. Efremova, Russian-Sino Cooperation in Education. // Vestnik RUDN. International Relations, 2017, 17 (4), pp. 857-865. DOI: 10.22363/2313-0660-2017-17-4-857-865.

[8] G. Ganshina, A. Tsvyk, Promotion of Russian Language in China As a Tool of Cultural Diplomacy of the Russian Federation. Proceedings of the 2016 International Conference on Arts, Design and Contemporary Education. Book Series: Advances in Social Science Education and Humanities Research. Volume: 64. France, Paris, Atlantis Press, 2016, pp. 1285-1289. Accession Number: WOS: 000389214900313.

[9] M.A. Konarovsky, Russia and the Shanghai Cooperation Organization: Some Elements of Strategy. 2016. International Organisations Research Journal, 11(4), pp. 149-161.

[10] G.Y. Grevtseva, Russia and China: cooperation in the education sphere. 2017. Bulletin of the South Ural State University. Ser. Education, Educational Sciences, 9(2), pp. 43-52. 